\title{
Biomass component equations for Latin American species and groups of species
}

\author{
José Návar* \\ Natural Resource Management, CIIDIR-IPN Unidad Durango, Calle Sigma s/n. Fraccionamiento 20 de Noviembre II, \\ Durango, Dgo. CP 34220, México
}

(Received 24 June 2008; accepted 4 November 2008)

Keywords:

intrinsically linear /

nonlinear and seemingly unrelated

regression /

weighting procedures

Mots-clés :

intrinsèquement linéaires /

non linéaires et apparemment sans lien

de régression /

procédures de pondération

\begin{abstract}
- Studies dealing with the estimation of biomass, site productivity and the contribution of forests to the global carbon balance require the use of allometric equations. There have been a great number of equations developed to estimate biomass components of trees and shrubs in various ecosystems. However, there are less literature compilations that address the calculations of biomass components. - I report a total of 229 sets of allometric equations to estimate biomass components for 102 species in 72 different forest communities of arid, semi-arid, subtropical, tropical and temperate Latin-American ecosystems.

- The selection of the appropriate allometric model is a key element in the accurate estimation of biomass, stand productivity, carbon stocks and fluxes, and as a consequence, it is important to apply special effort to the selection and estimation of biomass equations.

- I also discuss statistical methods of parameter estimation and recommend the dissection of two conventional allometric equations when biomass studies are conducted on a wide range of diameters. In order to use nondestructive procedures of biomass estimation such as the fractal theory, the null hypothesis that the mean slope $b$ value is equal to 2.67 was rejected for Latin American biomass species.

- This information is critical for the establishment of environmental projects that aim to estimate conventional parameters (i.e., productivity, habitat quality and fuel wood) as well as environmental features (i.e., stocks and fluxes of carbon and nitrogen).
\end{abstract}

Résumé - Équations des composantes de la biomasse pour des espèces et des groupes d'espèces d'Amérique latine.

- Les études portant sur l'estimation de la biomasse, la productivité des stations et la contribution des forêts à l'équilibre mondial du carbone nécessitent l'emploi d'équations allométriques. Il y a eu un grand nombre d'équations qui ont été développées pour estimer la biomasse des composantes des arbres et des arbustes dans différents écosystèmes. Cependant, il existe beaucoup moins de compilations de la littérature scientifique qui portent sur les calculs des composantes de la biomasse.

- Je rapporte un total de 229 séries d'équations allométriques pour estimer les composantes de la biomasse de 102 espèces différentes dans 72 communautés forestières des zones arides, semi-arides, sub-tropicales, tempérées des écosystèmes latino-américains.

- La sélection du modèle allométrique est un élément clé pour l'estimation précise de la biomasse, de la productivité des stations, des stocks de carbone et des flux et, en conséquence, il est important de bien sélectionner les équations permettant l'estimation de la biomasse.

- J'ai également discuté les méthodes statistiques d'estimation des paramètres et recommandé la dissection des deux équations allométriques classiques lorsque les études sur la biomasse sont conduites sur une large gamme de diamètres. Afin d'utiliser les procédures non destructives d'estimation de la biomasse telles que la théorie des fractales, l'hypothèse nulle que la pente moyenne $b$ a une valeur égale à 2,67 a été rejetée pour la biomasse des espèces de l'Amérique latine.

- Cette information est critique pour la mise en place de projets environnementaux qui visent à estimer des paramètres classiques (c'est-à-dire, la productivité, la qualité du site, le bois de chauffage), ainsi que des caractéristiques environnementales (c'est-à-dire, les stocks et les flux de carbone et d'azote).

\footnotetext{
*Corresponding author: jnavar@ipn.mx
} 


\section{INTRODUCTION}

The estimation of biomass components of trees and forests has long been studied to aid the quantification of available forest resources, such as food, fuel, fodder and fiber (Agee, 1983; Beskerville, 1965; Kie and White, 1985). At the present time, forest biomass data can also be used to understand changes in forest structure resulting from succession, or in differentiation between forest types (Gehring et al., 2004; Vargas et al., 2008). In recent years, the estimation of biomass components has become important for environmental projects, since biomass can be related to carbon stocks and to carbon fluxes when biomass is sequentially measured over time (Brown et al., 1989; Jenkins et al., 2001; Schroeder et al., 1997). Potential changes in the other carbon pools of the ecosystem (litter, coarse woody debris, root biomass, soil organic matter) can be further derived from allometric equations by estimating the relative prevalence of biomass components.

The development and use of allometric equations is the standard methodology to estimate the biomass of tree components (Brown and Iverson, 1992; Brown et al., 1989; Gillespie et al., 1992; Chavé et al., 2001; 2003; Návar, 2004a; 2009). Other approaches include volume estimation multiplied by the wood specific gravity (Castedo-Dorado, 2007; Mohren and Klein Goldewijkt, 1990). Theoretical, nondestructive approaches include the use of fractal techniques (West et al., 1999) where the main assumption is that diameter at breast height, $D$, is related to biomass, $M$, by $D<M^{3 / 8}$, indicating that the scaling exponent $b$ in the allometric equation equals 2.67 (see also Enquist et al., 1998). Discussions regarding this theoretical approach are ongoing (Pilli et al., 2006; Zianis and Mencuccini, 2004).

In the meantime, there is an urgent need for local, regional and national estimates of biomass and carbon density. The traditional technique for estimating the density of forest carbon stocks and fluxes is based on forest inventories and allometric relationships between the above-ground biomass (TAB) of a tree and its trunk diameter (Brown 1997; Clark et al., 2001). Brown et al. (1989) and Chavé et al. (2001; 2003) reported methods for using existing forest inventory data to estimate biomass densities of tropical forests. However, for forests with complex diversity structure, there is a lack of allometric equations to estimate biomass components, resulting in deviations from observed and estimated biomass components (Araujo et al., 1999; Chavé et al., 2001; 2003). There is also a lack of allometric equations developed on-site, and thus, extrapolation is common in most studies. Although in the last few decades there has been a significant effort to develop and compile biomass component equations (i.e., Ter-Mikaelian and Korzukhin (1997), and Zianis and Mencuccini (2004) who reported a list of allometric biomass equations for 67 and 227 North American and worldwide species, respectively), there are still numerous allometric equations in the literature that have been derived from harvested trees of many species for many sites.

Efforts to compile biomass component equations, such as those of Ter-Mikaelian and Korzukhin (1997) for North American tree species, and Zianis and Mencuccini (2004) for world- wide species, should continue for the numerous biomass component equations that have not yet been brought together. There is an urgent need for biomass component equations to: (a) develop sound practical environmental projects of regeneration of degraded forests with the right species, (b) project biomass and carbon stocks in advance of regeneration projects, and (c) calculate goods and services provided by natural and regenerated tree species in the early stages of development. The objectives of this report were thus: (a) to compile a set of biomass component equations for Latin American species and groups of species or forests, (b) to describe the statistical techniques employed in parameter estimation to discuss the robustness and weakness of these techniques, and (c) to test the hypothesis that the scaling exponent $b$ in the allometric equation equals 2.67 .

\section{MATERIALS AND METHODS}

For this report, I searched the literature for biomass equations developed over the last 20 years in all journals published by Elsevier, Blackwell and Springer Verlag Scientific Publications. The search procedure included the keywords biomass equations, allometric equations, and Latin American biomass species. In addition, a search in Google for biomass equations was conducted with the keywords "ecuaciones de biomasa". Equations found in the literature provide biomass estimates for several diameter ranges and the statistical techniques to estimate parameters are also reported. Allometric equations were classified by vegetation type found in Latin America: arid-subtropical species, temperate and tropical species. Groups of species are defined here as two or more species that have one single allometric equation for one single biomass component. Allometric equations are classified as dry-subtropical, temperate and tropical vegetation types. In addition to the set of equations, I present the species or group of species, the biomass component, the reference where the equation can be found for further information, the diameter range where the equation applies, the number of trees harvested to develop the equation, the statistical technique employed to estimate equation parameters and the plant community where trees were harvested.This information will be useful if scientists or forest resource managers are interested in developing a single allometric equation for each vegetation type.

Examples of the main statistical techniques employed to estimate biomass component equation parameters are presented with two examples: (a) complex Tamaulipan thornscrub forests of northeastern Mexico (Návar et al., 2004a) and (b) pine forests restricted to a diameter range (Návar et al., 2004b) to explore weakness and robustness of biomass equations.

The hypothesis that the mean $b$ slope value of the allometric relationships (a) $\operatorname{Ln}(\mathrm{TAB})=a+b \operatorname{Ln}(D)$ or (b) $\mathrm{TAB}=a D^{b}$ is 2.67 was tested to probe the fractal theory of West et al. (1999) to use in upcoming nondestructive allometric estimations. Therefore, the average $b$ value from the compiled empirical equations $\left(b_{\text {emp }}\right)$ was compared with the theoretical one (2.67). West et al. (1999) suggested that $M$ should scale against $D$ with a universal exponent $(b=8 / 3)$, because the scaling exponent would depend on an optimal tree architecture. Moreover, the a parameter should be related to the wood density $(\rho)$ (Enquist et al., 1998).

The fractal theory uses the relationship between $D$ and $H$ to estimate $b$. This data has been modeled for several forest species (i.e., 
Saunders and Wagner, 2008). However, this data was not available for most allometric equations, therefore I could not estimate parameters $b$ or, henceforth, a using the fractal theory. Simple comparisons of mean $b$ values $\left(b_{\text {emp }}\right)$ of reported allometric equations with the universal 8/3 estimate have been previously conducted (e.g., Pilli et al., 2006; Zianis and Mencuccini, 2004). To accomplish this contrast, first the normality tests of the $b$ values were calculated using the KolmogorovSmirnoff and Shapiro-Wilk statistics, and second the estimates of the standard deviation and confidence intervals provided information to test whether the mean $b$ slope value is equal or different to 2.67. In addition, the probability that the estimated $b$ values from the reported studies will be equal to or larger than 2.67 was estimated using the normal approach, since $b\left(b_{\mathrm{emp}}\right)$ values fitted this density function well.

A total of 78 allometric equations (log-transformed and nonlinear regression) meet the requirements for testing the hypothesis that $b=$ 2.67. These equations estimate only total aboveground biomass in $\mathrm{kg}$ using diameter at breast height in $\mathrm{cm}$. Of these, 5, 45 and 28 come from trees or shrubs of semi-arid - subtropical, tropical and temperate climates, respectively. Mean (confidence interval) diameter at breast height was $22 \mathrm{~cm}$ (4); but varied among forest types from $17 \mathrm{~cm} \mathrm{(10)}$ and $25 \mathrm{~cm} \mathrm{(4)} \mathrm{to} 21 \mathrm{~cm} \mathrm{(7)} \mathrm{in} \mathrm{semi-arid} \mathrm{subtropical,} \mathrm{temperate} \mathrm{and}$ tropical forests, respectively.

\section{RESULTS AND DISCUSION}

The search successfully identified a set of 229 allometric equations to estimate biomass components for 102 (26 for drysubtropical, 26 for temperate and 50 for tropical) species and for 72 ( 4 for dry-subtropical, 11 for temperate and 57 for tropical) different groups of species in Latin America. Of the 229 allometric equations, 35, 52 and 142 were derived for studies of dry to subtropical, temperate and tropical forests, respectively. Allometric equations for Latin American species and forests are presented in Table I (available only at www. afs-journal.org).

\subsection{Statistical techniques to estimate equation parameters}

A variety of statistical techniques to estimate parameters were reported in this literature search, including linear, nonlinear, intrinsically linear, seemingly unrelated linear regression, and seemingly unrelated nonlinear regression. Linear regression usually takes the form of $\mathrm{TAB}=\alpha+\beta\left(D^{2} H\right)$; nonlinear regression takes the form $\mathrm{TAB}=\alpha \mathrm{D}^{\beta}$; and intrinsically linear regression takes the form $\operatorname{Ln}(\mathrm{TAB})=\alpha+\beta \operatorname{Ln}(D)$. The intrinsic linear regression requires a weighting parameter since the logarithmic transformation compresses the data to calculate regression parameters without heteroscedasticity problems. When the original units are re-transformed, the largest biomass values are usually underestimated. Bekersville (1965) recommended that in this correction, the weighting factor could be calculated from $\mathrm{CF}=\exp (\mathrm{MSE} / 2)$, where; $\mathrm{CF}=$ correction factor, and MSE = mean square error of the regression analysis of variance. Seemingly unrelated regression is the recommended statistical technique since biomass components are related; i.e. leaf biomass is related to branch biomass, this is related to bole biomass, and all these components are related to total aboveground biomass (Cunia and Briggs, 1984; 1985; Parresol, 1999). Therefore, a set of biomass component equations take the following forms: for seemingly unrelated linear (e.g., $T A B=B l+B b r+B b o ; B l=\alpha l+\beta l\left(D^{2} H\right)+B b r=$ $\left.\alpha b r+\beta b r\left(D^{2} H\right)+B b o=\alpha b o+\beta b o\left(D^{2} H\right)\right)$, and for unrelated nonlinear $\left(T A B=B l+B b r+B b o ; B l=\alpha l D^{\beta l}+B b r=\right.$ $\left.\alpha b r D^{\beta b r}+B b o=\alpha b o D^{\beta b o}\right)$ regressions: where $T A B=$ total aboveground biomass; $B l=$ foliage biomass, $B b r=$ branch biomass; $B b o=$ bole biomass; and $\alpha$ and $\beta$ are statistical parameters that are independently estimated and restricted to provide total aboveground biomass.

Using an example reported by Návar et al. (2004a) for the biomass components foliage, branches and boles of 913 semiarid, subtropical shrubs of northeastern Mexico, nonlinear and seemingly unrelated (non-) linear regressions least biased total aboveground biomass, in contrast to the linear regression applied to the logarithm of the data using a correction factor for complex Tamaulipan thornscrub trees (Fig. 1). The allometric equation with the weighting factor improves the prediction of the biomass component in contrast to the conventional logtransformed linear model, but it is still skewed for this data. This usually happens for biomass data that contains small and large trees, where there is frequently an inflexion point between these two types of biomass data. Therefore, in order to fit the conventional biomass equations (log-transformed data or intrinsically linear) it is necessary to develop two equations, where one is used for small and the second one is used for large trees, or to use nonlinear and seemingly unrelated (non-) linear regression techniques to fit this data.

Using a more compacted example reported by Návar et al. (2004b), all regression techniques reported in Table I produce similar biomass estimates for small pine trees of Durango, Mexico (Fig. 2).

\subsection{Testing the fractal theory that the slope equals 2.67}

The $a$ and $b$ values are negatively related fitting a power function with the following equation $a=2.178 b^{-0.03}$ (Fig. 3). When $M$ is expressed in $\mathrm{kg}$ and $D$ in $\mathrm{cm}$, this equation is similar to that reported by Návar (2009) as $a=5.1385 b^{-4.4857}$ for coniferous forests of northwestern Mexico as well as to the equation of $a=7.0281 b^{-4.7558}$ reported for 277 compiled biomass studies by Zianis and Mencuccini (2004). Three similar equations were reported by Pilli et al. (2006) for young, juvenile and mature trees, showing the consistency of these biomass equations and the relationship between $\mathrm{a}$ and $\mathrm{b}$. These regression equations are consistent, although the statistical parameters of this equation were calculated for all forest types, combining log-transformed data and nonlinear regression techniques to estimate parameters. Large deviations in this relationship could be explained by the variability of species and forests, stages of development, and both statistical techniques employed in parameter estimation.

The summation of the mean empirical parametric values a and $\mathrm{b}$ of the allometric equations equals 2.5364 and this outcome supports that $2<d+h<3$. The mean $( \pm$ confidence 

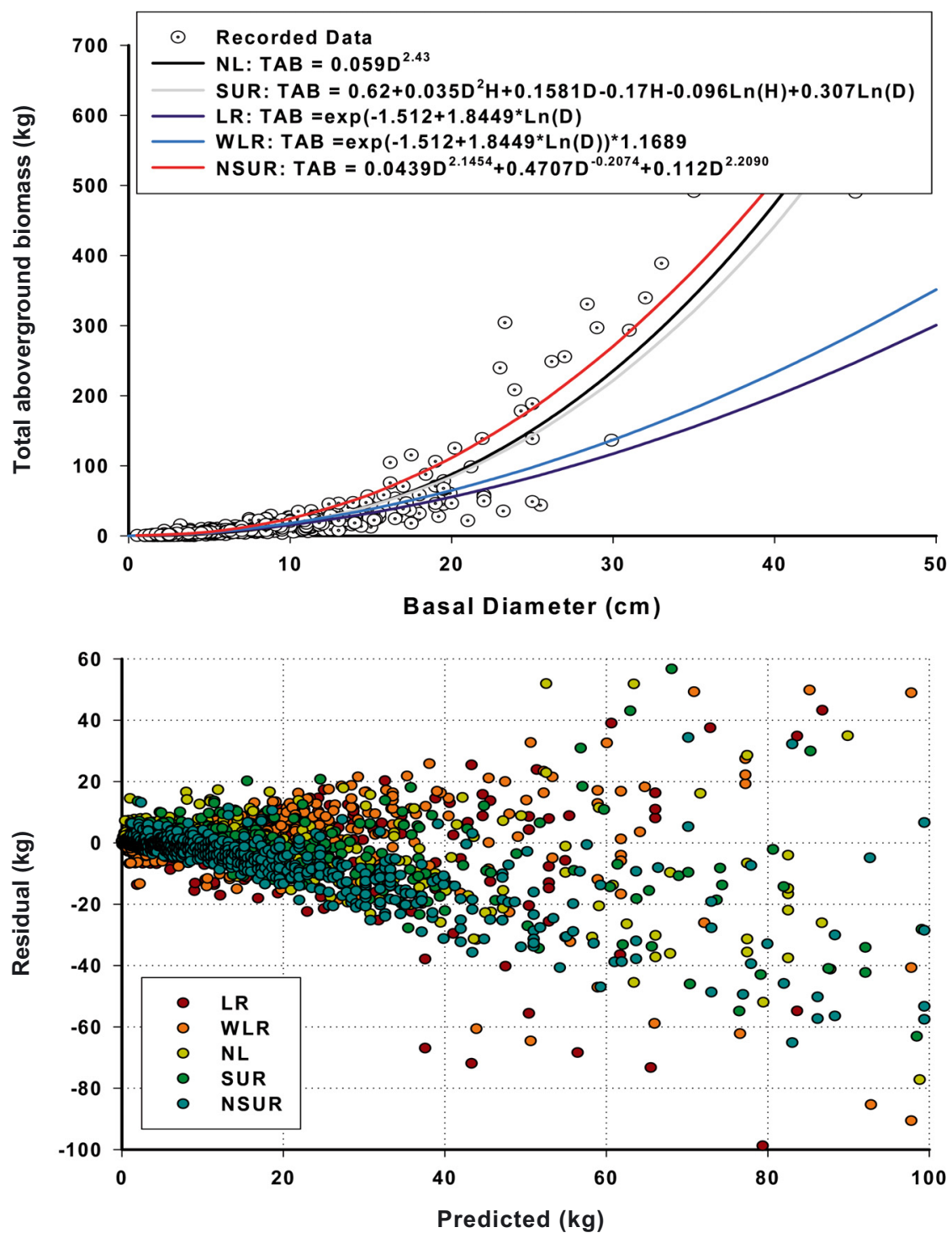

Figure 1. Five allometric equations and their residuals to estimate biomass for 913 shrubs and small trees of northeastern Mexico (d'après Návar et al., 2004a); LR = Linear, NL = Nonlinear, WLR = Weighted Linear, SUR = Seemingly unrelated Linear and NSUR $=$ Seemingly unrelated nonlinear regressions. (A color version of this figure is available at www.afs-journal.org.)

interval) value of the slope for 78 allometric equations was $2.3785( \pm 0.05148)$, with a standard deviation of 0.2319 . The mean $b$ slope value ( \pm confidence intervals) shows that this figure is smaller than the theoretical value of the slope $(8 / 3)$. This finding is also consistent with the observations of Zianis and Mencuccini (2004), who recorded an average $b$ value of $2.3679( \pm 0.016)$ for 279 biomass studies. Pilli et al. (2006) demonstrated that the $b$ values of allometric equations developed at the adult stage (2.64) were not significantly different than the theoretical $b$ value, showing that the fractal theory applies well for trees at the adult stage but not for trees at younger or more mature stages.

The mean (confidence interval) a value was $0.16(0.03)$ and it deviates notoriously from the basic wood density, $p$, values for these species. Mean basic density values reported for pine and broadleaf trees are 0.40 and $0.64 \mathrm{~g} \mathrm{~cm}^{-3}$, respectively (Fuentes-Salinas, 1995).

The Kolmogorov-Smirnoff and the Shapiro-Wilk tests accepted the null hypothesis that the slope data distributes normally, since the maximum deviation between observed and estimated probability was 0.069 and 0.97 with probabilities of $p=0.15$ and $p=0.079$, respectively. Based on this information, $68 \%$ of the slope data falls within the interval of $2.14 \rightarrow$ 2.61. The probability that the slope value is equal to or larger than 2.67 is $z=(2.3785-2.667) / 0.2319=z=-1.2436$; $P(\mathrm{z})=0.1068$. Using the empirical b slope data, 7 out of 78 counts surpassed the value of 2.67 , calculating a probability of 0.089 . In other words, the slope surpasses the value of 2.67 in only 10 out of 100 counts. 

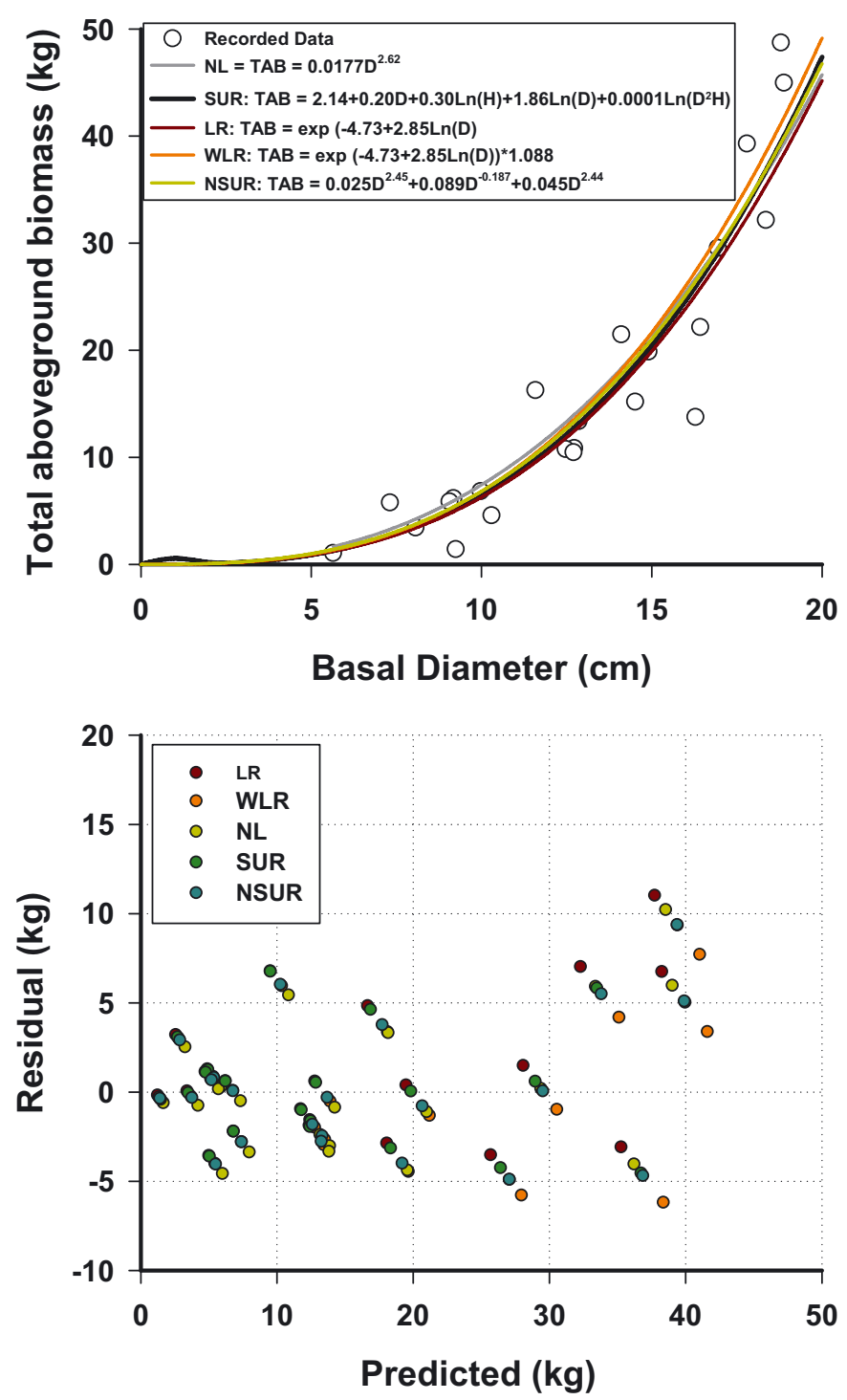

Figure 2. Five allometric equations and their residuals to estimate biomass for 25 small pine trees of $P$. durangensis of Durango, Mexico (Source: Návar et al., 2004b) ; LR = Linear, NL = Nonlinear, WLR $=$ Weighted Linear, SUR $=$ Seemingly unrelated Linear and NSUR $=$ Seemingly unrelated nonlinear regressions. (A color version of this figure is available at www.afs-journal.org.)

The slopes and mean diameters statistically fit well with a power function (Fig. 4). The slope of this relationship is negative with a value of less than $1(-0.018)$. The value of the mean predicted slope augments with decreasing mean diameters. In the range of recorded mean diameters it never attains the 2.67 value proposed by Enquist et al. (1998) and West et al. (1999) for Latin American forests. Forecasts using the power equation project that the mean diameter of trees must be in the range of 0.001 to attain a mean slope value of 2.67 , indicating that the fractal theory could also apply to seedlings, as was noted for mature trees by Pilli et al. (2006).

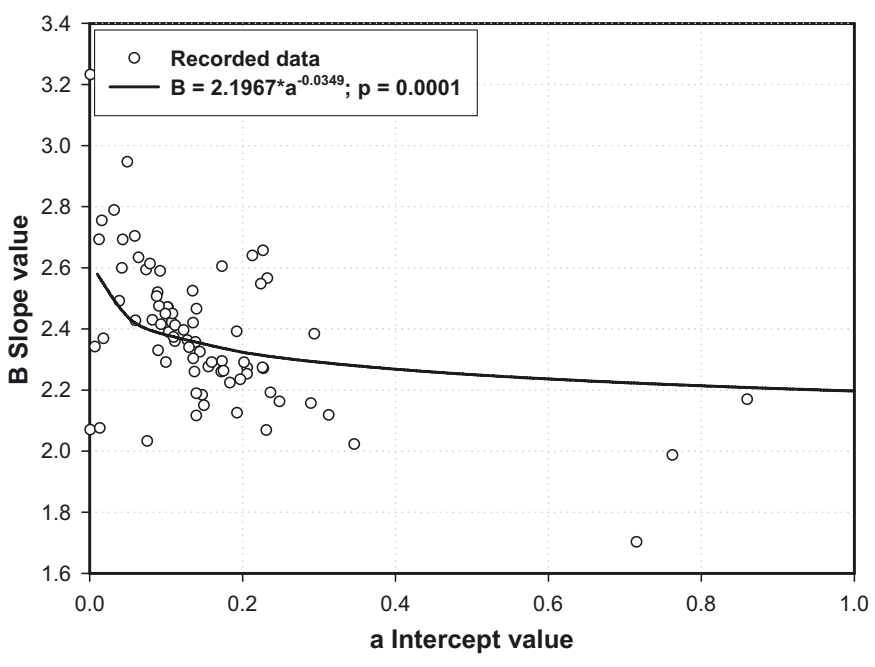

Figure 3. The relationship between the slope and the intercept for 78 allometric equations that estimate total aboveground biomass as a function of DBH.

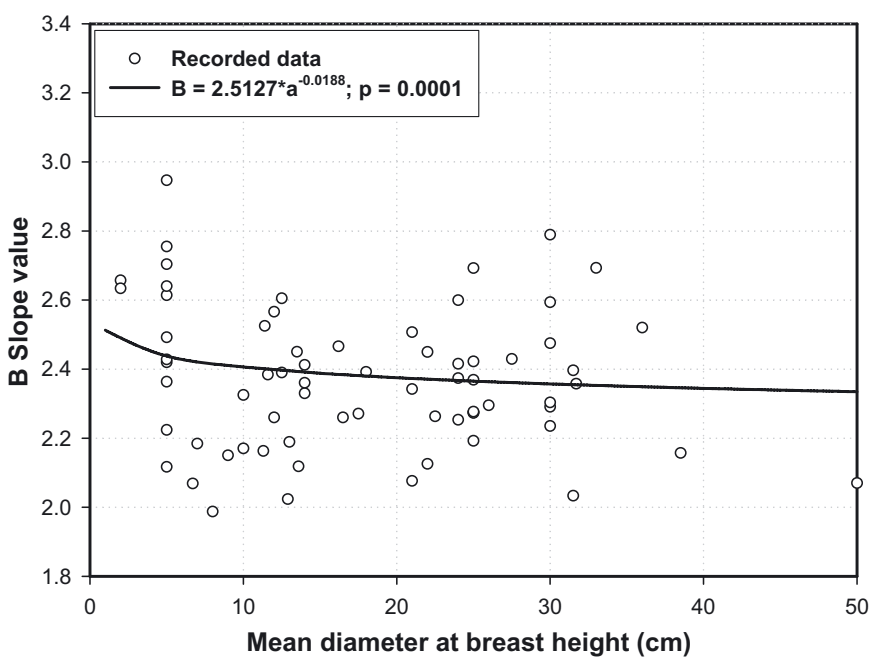

Figure 4. The relationship between the slope and the mean diameter for 78 allometric equations that estimate total aboveground biomass as a function of DBH.

Mean slope values differ between forest types; from 2.24 in subtropical and 2.32 in temperate to 2.41 in tropical forests, although they were not significantly different. It is likely that in addition to the stage of tree maturity, as observed by Pilli et al. (2006) and noted in this study, the type of forest may also contribute to testing the fractal theory well in biomass estimation.

The mean slope value (2.3785) and its confidence interval (0.051) indicates that the 2.67 slope value proposed by Enquist et al. (1998) and West et al. (1999) is statistically different from the mean slope value for Latin American species. Thus, these findings suggest that further research is necessary to fulfill the potential of fractal geometry for application in forest biomass studies since the empirical values observed provide better biomass estimates than the theoretical calculations. 
Thus, it is confirmed that the potential of fractal geometry has not been fully investigated and further research is necessary to reveal its value in forest biomass studies, since it can be obviously noted that the empirical value provides better biomass estimates.

\section{CONCLUSIONS}

In this manuscript, I report a total of 229 equations for several biomass components, including boles, branches, foliage, bark and roots for Latin American species and groups of species. Of the total, 110 were reported for individual species and the remaining were reported for groups of species. The most common statistical techniques employed in parameter estimation were log-transformed data combined with linear regression, nonlinear regression, and seemingly unrelated linear and nonlinear regressions. Diameter at breast height, basal diameter, top height, basal area and basic wood density are common independent variables. Reported statistical techniques to estimate parameters are linear, nonlinear, intrinsically linear, and seemingly unrelated nonlinear and linear regression. I briefly explain the weakness and robustness of these techniques with two examples. I also tested the null hypothesis that the mean slope $=2.67$, and the data collected on the slopes of the allometric equations did not support this hypothesis. Therefore, it is concluded that the fractal technique requires additional study to further elucidate the slope value of the allometric equation for Latin American species.

\section{REFERENCES}

Agee J.K., 1983. Fuel weighting for understory-grown conifers in southern Oregon. Can. J. For. Res. 13: 648-656.

Albarran V. and Zerpa F., 1992. Modelos matemáticos para generar tablas de volumen y peso verde en plantaciones de Pinus caribaea var. Hondurensis del oriente Venezolano. Boletín Técnico \# 5. C.V.G.PROFORCA, Edo. Monagas.

Alvarez E., 1993. Composición florística, diversidad, estructura y biomasa de un bosque inundable en la Amazonia Colombiana. Tesis de Maestria en Biología, Universidad de Antioquia, Facultad de Ciencias Naturales y Exactas, Medellín, Colombia.

Alvarez E., 2001. Comparación de ecuaciones para la estimación de la biomasa de árboles, palmas y lianas en un bosque inundable de la Amazonia Colombiana. Simposio Internacional Medición y Monitoreo de la captura de Carbono en Ecosistemas Forestales. Valdivia, Chile 18-20 de Octubre de 2001.

Araujo T.M., Higuchi N., and Carvalho J.A., 1999. Comparison of formulae for biomass content determination in a tropical rain forest site in the state of Para, Brazil. For. Ecol. Manage. 117: 43-52.

Ares A., Boniche J., Quesada J.P., Yost R., Molina E., and Smyth T.J., 2002. Estimación de biomasa por métodos alométricos, nutrimientos y carbono en plantaciones de palmito en Costa Rica. Agronomía Costarricense 26: 19-30.

Beekman F., 1981. Structural and dynamic aspects of the occurrence and development of lianes in the tropical rain forest. Department of Forestry, Agricultural University, Wageningen, The Netherlands.

Bekersville G.L., 1965. Dry matter production in immature balsam fir stands. Forest Science Monograph. Society of American Foresters, Washington, DC, $41 \mathrm{p}$.
Bhatti J.S., Foster N.W., Oja T., Moayeri M.H., and Arp P.A., 1998. Modelling potentially sustainable biomass porductivity in jack pine forest stands. Can. J. Soil Sci. 78: 105-113.

Brandeis T.J., Delaney M., Parresol B.R., and Royer L., 2006. Development of equations for predicting Puerto Rican tropical dry forest biomass and volume. For. Ecol. Manage. 233: 133-142.

Bratti M.R., Wrann J.H., and Vita A.A., 1998. Efecto de la altura de corte en el rebrote de Acacia saligna (Labill.) H. Wendl. Ciencia e Investigación Forestall - Instituto Forestal / Chile 12: 40-50.

Brown S., 1997. Los bosques y el cambio climático: el papel de los terrenos forestales como sumideros de carbono. In Actas del XI Congreso Mundial Forestal: Recursos Forestales y Arboles. Vol 1. Antalya, Turkia 13-22 October 1997.

Brown S., Gillespie A.J., and Lugo A.E., 1989. Biomass estimation methods for tropical forests with aplications to forest inventory data. For. Sci. 35: 881-902.

Brown S. and Iverson L.R., 1992. Biomass estimates for tropical forests. World Resour. Rev. 4: 366-384.

Cairns M.A., Olmsted I., Granados J., and Argaez J., 2003. Composition and aboveground tree biomass of a dry semi-evergreen forest on Mexico's Yucatan Peninsula. For. Ecol. Manage. 186: 125-132.

Carvalho Jr., Higuchi J.A., Araujo N., and Santos J.C., 1998. Combustion completeness in a rainforest clearing experiment in Manaus, Brazil. J. Geophys. Res. 103:D11, 13,915-13,199.

Castañeda-Mendoza A., Vargas-Hernández J., Gómez-Guerrero A., Valdez-Hernández J.I., and Vaquera-Huerta H., 2004. Acumulación de carbono en la biomasa áerea de una plantación de Bambusa oldhamii. Agrociencia 39: 107-116.

Castedo-Dorado F., Diéguez-Aranda U., Barrio Anta M., and Álvarez González J.G., 2007. Modelling stand basal area growth for radiata pine plantations in Northwestern Spain using the GADA. Ann. For. Sci. 64: 609-619.

Castellanos J.F., Velázquez-Martínez A., Vargas-Hernández J., and Rodríguez-Franco C., 1993. Producción de biomasa en un rodal de Pinus patula Schl. and Cham. I Congreso Mexicano de Recursos Forestales, Saltillo, México.

Chambers J.Q., dos Santos J., and Ribeiro R.J., 2001. Tree damage, allometric relationships, and above-ground net primary production in central Amazon forest. For. Ecol. Manage. 152: 73-84.

Chavé J., Riera B., and Dubois M.A., 2001. Estimation of biomass in a neotropical forest of French Guiana: spatial and temporal variability. J. Trop. Ecol. 17: 79-96.

Chavé J., Condit R., Lao S., Caspersen J.P., Foster R.B., and Hubbell S.P., 2003. Spatial and temporal variations of biomass in a tropical forest; results from a large census plot in Panama. J. Ecol. 91: 240-252.

Clark D.A., Brown S., Kicklighter D.W., Tomlison J.Q., and Ni J., 2001. Measuring net primary production in forests; concepts and field methods. Ecol. Appl. 11: 356-370.

Cole T.G. and Ewel J.J., 2006. Allometric equations for tour valuable tropical tree species. For. Ecol. Manage. 229: 351-360.

Colorado G.J., 2001. Ecuaciones de biomasa aérea para los árboles de los bosques secundarios del área de influencia de la Central hidroeléctrica Porce II. Trabajo de grado para optar por el título de Ingeniero Forestal, Universidad Nacional de Colombia, Medellín, Colombia.

Crow T.R., 1980. A rainforest chronicle: a 30-year record of change in structure and composition at El Verde, Puerto Rico. Biotropica 12: $42-55$.

Cruz G.M. and Quintana A.G., 2008. Funciones de biomasa para una plantación de 7 años de Quillaza saponaria Mol. En el secano interior de Chile Central. http://www.umayor.cl/jornadas/forestales/ descargas/trabajos/trabajos_0014.pdf. 
Cunia T. and Briggs R.D., 1984. Forcing additivity of biomass tables some empirical results. Can. J. For. Res. 14: 376-384.

Cunia T. and Briggs R.D., 1985. Forcing additivity of biomass tables - use of the generalized least-square method. Can. J. For. Res. 15: $23-28$.

DeWalt S.J. and Chave J., 2004. Structure and biomass of four lowland neotropical forests. Biotropica 36: 7-19.

Dias A.T.C., de Matos E.A., Vieira S.A., Azeredo J.V., and Scarano F.R., 2006. Aboveground biomass stock of native woodland on a Brazil sandy coastal plain: estimates based on the dominant tree species. For. Ecol. Manage. 226: 367-367.

Durán-Garáte L.P., 2005. Evaluación de la producción y productividad en biomasa aérea de boldo (Peumus boldus Mol.) en un bosque esclerófilo de la comuna de María Pinto, Provincia de Melipilla, Region Metropolitana. Memoria para optar al título profesional de Ingeniero Forestal, Facultad de Ciencias Forestales, Universidad de Chile.

Enquist B.J., Brown J.H., and West J.B., 1998. Allometric scaling of plant energetics and population density. Nature 395: 163-165.

Etchevers-Barra J.D., Vargas-Hernández J., Acosta-Mireles M., and Velásquez-Martínez A., 2002. Estimación de la biomasa aérea mediante el uso de relaciones alométricas en seis especies arbóreas en Oaxaca, México. Agrociencia 36: 725-736.

Farinha-Watzlawick L., Sanquetta C.R., de Mello A.A., and Arce J.E., 2001. Ecuaciones de biomasa aérea em plantaciones de Araucaria angustifolia en el Sur del Estado de Paraná, Brasil. Simposio Internacional de Medición y Monitoreo de la Captura de Carbono en Ecosistemas Forestales, Valdivia, Chile, 18-21 Octubre de 2001.

Feldpausch T.R., McDonald A.J., Passos C.A.M., Lehmann J., and Riha S.J., 2006. Biomasa, harvestable area, and forest structure estimated from commercial forest inventories and remote sensed imagery in Southern Amazonia. For. Ecol. Manage. 233: 121-132.

Fernández-Tschieder E., Martiarena R., Goya J., Lupi A., and Frangi J., 2008. Determinación de la biomasa aérea de plantaciones de Araucaria angustifolia (Berth) O. KTZE en el norte de la Provincia de Misiones. 11as Jornadas Técnicas Forestales y Ambientales, FCF UnaM, EEA, Montecarlo, INTA. Argentina, http://www.inta.gov.ar/ montecarlo/info/documentos/forestales/f_tschieder.pdf

Ferrando J.J., Goya J.F., Barrera M.D., Yapura P.F., and Frangi J.L., 2001. Biomasa y productividad aérea de Austrocedrus chilensis en Río Negro, Argentina. Revista de la Facultad de Agronomía de la Plata 104: 139-149.

Frangi J.L. and Lugo A.E. 1985. Ecosystem dynamics of a sub-tropical floodplain forest. Ecol. Monogr. 55: 351-369.

Fuentes-Salinas M., 1995. Tecnologìa de la Madera II. Propiedades Físico-Mecánicas, División de Ciencias Forestales, Universidad Autónoma Chapingo, Chapingo, México, 64 p.

Gaillard de Benitez C., Pece M., Juarez de Galíndez M., Maldonado A., Acosta V.H., and Gomez A., 2002. Biomasa aerea de ejemplares de Quebracho blanco (Aspidosperma quebracho-blanco) en dos localidades del Parque Chaqueño seco. Quebracho 9: 115-127.

Gehring C., Park S., and Denich M., 2004. Liana allometric biomass equations for Amazonian primary and secondary forest. For. Ecol. Manage. 195: 69-83.

Gerwin J.J. and Farias D.L., 2000. Integrating liana abundance and forest stature into an estimate of total aboveground biomass for an eastern Amazonian forest. J. Trop. Ecol. 16: 327-335.

Gillespie A.J.R., Brown S., and Lugo A.E., 1992. Tropical forest biomass estimation from truncated stand tables. For. Ecol. Manage. 48: 68-87.

Giraldo L.A., Zapata M., and Montoya E., 2007. Estimación de la captura y flujo de carbono en silvopastoreo de Acacia mangium asociada con Brachiaria dyctioneura en Colombia. http://dict.isch.edu.cu/dict/ publicacionesdeeventos/agroforesteria\%202007/data/conferencias/ luisagiraldo.pdf.
Guerra J.C., Ganoso J.A. Schlatter J.V., and Nespolo R.R., 2005. Análisis e la biomasa de las raíces en diferentes tipos de bosques. Avances de la evaluación de Pinus radiata en Chile. Bosque (Valdivia) 26: 5-21.

Hase H. and Folster H., 1983. Impact of plantation forestry with teak (Tectona grandis) on the nutrient status of young alluvial soils in west Vnezuela. J. Soil Sci. 39: 123-133.

Higuchi N., Santos J., Ribeiro R.J., Miente L., and Biot Y., 1998. Biomassa da parte aérea da vegetação da floresta tropical úmida da Terra Firme da Amazônia Brasileira. Acta Amazônica 28: 153-166.

Hughes R.F., Kauffman J.B., and Jaramillo V.J., 1999. Biomass, carbon, and nutrient dynamic of secondary forests in a humid tropical region of Mexico. Ecology 80: 1892-1907

Hughes R.F., Kauffman J.B., and Jaramillo V.J., 2000. Ecosystem-scale impacts of deforestation and land use in a humid tropical region of Mexico. Ecol. Appl. 10: 515-527.

Jenkins J.C., Birdsey R.A., and Pan Y., 2001. Biomass and NPP estimation for the mid-atlantic region (USA) using plot-level forest inventory data. Ecol. Appl. 11: 1174-1193.

Jenkins J., Chojnaky D., Heath L., and Birdsey R., 2004 Comprehensive database of diameter-based biomass regressions for North American tree species. US Department of Agriculture, Forest Service, Delaware, USA, $48 \mathrm{p}$.

Kie J.G. and White M., 1985. Population-dynamics of white-tailed deer (Odocoileus virginianus) on the Welder wildlife refuge, Texas. Southwestern Naturalist 30: 105-118.

Kue R. and Lim M., 1999. Forest biomass estimation in Air Hitam Forest Reserve, May 2002 (electronic version), [http://www.geocities.com/ EnchantedForest/Palace/1170/biomass.html].

Kumar K. and Tewari V.S., 1999. Above ground biomass tables for Azadirachta indica A. Juss. Int. For. Rev. 1: 111-112.

Laclau P. 2003. Biomasa and carbon sequestration of ponderosa pine plantations and native cypress forests in northwestern Patagonia. For. Ecol. Manage. 173: 353-360.

Lapeyre T., Alegre J., and Arévalo L., 2004. Determinación de las reservas de carbono de la biomasa aerea en diferentes sistemas de uso de la tierra en San Martín, Perú. Universidad Nacional Agraria La Molina, Lima, Perú.

Loguercio G.A. and Defossé G., 2001. Ecuaciones de biomasa aérea, factores de expansión y reducción de la lenga Nothofagus pumilio (OPEP et Endl.) Krasser en el SO de Chubut, Argentina. Simposio Internacional sobre Medición y Monitoreo de la Captura de Carbono en Ecosistemas Forestales. Valdivia, Chile 18-20 de Octubre de 2001.

Martinez-Yrizar A. Sarukhan J., Perez-Jimenez A., Rincon E., Maass J.M., Solis-Magallanes A., and Cervantes L., 1992. Above-ground phytomass of a tropical deciduous forest on the coast of Jalisco, Mexico. J. Trop. Ecol. 8: 87-96.

Medeiros T.C.C. and Sampaio E.V.S.B., 2007. Allometry of aboveground biomasses in mangrove species in Itmaraca, Pernambuco, Brazil. Wetl. Ecol. Manage. 1: 1-8.

Mohren F. and Goldewijkt K., 1994. $\mathrm{CO}_{2}$ Fix model. Institute of forestry and nature research, Wageningen, Netherlands.

Monroy C.R. and Navar J., 2004. Ecuaciones de aditividad para estimar componentes de biomasa de Hevea brasiliensis Muell Arg. En Veracruz, México. Madera y Bosques 10: 29-43.

Montero M. and Montagnini F., 2004. Modelos alométricos para la estimación de biomasa de diez especies nativas en plantaciones en la región Atlántica de Costa Rica. Revista Forestal Centroamericana (in press).

Montero M.M. and Kanninen M., 2005. Terminalia amazonia; ecología y silvicultura. Serie Técnica. Informe Técnico No. 339, CATIE, Turrialba, Costa Rica.

Návar J., Méndez E., Nájera A., Graciano J., Dale V., and Parresol B., 2004a. Biomass equations for shrub species of Tamaulipas thornscrub of northeastern Mexico. J. Arid Environ. 59: 657-674. 
Návar J., González N., Maldonado D., Graciano J., Dale V., and Parresol B., 2004b. Additive biomass equations for pine species of forest plantations of Durango, Mexico. Madera y Bosques 10: 17-28.

Návar J., 2009. Allometric equations for tree species and forests of northwestern Mexico. For. Ecol. Manage. 257: 427-434.

Northup B.K., Sitzer S.F., Archer S., McMurtry C.R., and Boutton T.W., 2005. Above-ground biomass and carbon and nitrogen content of woody species in a subtropical thornscrub parkland. J. Arid Environ. 62: 23-43.

Ortiz E., 1997. Estimación de la Biomasa arriba del suelo en árboles de un bosque húmedo tropical. En: Conservación del Bosque en Costa Rica. Ed. EM Flores. Academia Nacional de Ciencias. San José, Costa Rica.

Overmann J.P., Witte H.J., and Saldarriaga J.G., 1994. Evaluation of regression models for aboveground biomass determination in Amazon rainforest. J. Trop. Ecol. 10: 207-218.

Pacheco-Escalona F.C., Gómez-Guerrero A., Aldrete A., FierrosGonzález A.M., and Cetina-Alcalá V., 2007. Absorción de nitrógeno y crecimiento de Pinus greggii Engelm. Seis años después de una poda química de raíz. Agrociencia 41: 675-685.

Padrón E. and Navarro-Cerrillo R., 2004. Estimation of above-ground biomass in naturally occurring populations of Prosopis pallida $(\mathrm{H}$. \& B. ex. Willd.) H.B.K. in the north of Peru. J. Arid Environ. 56: 283-292.

Parresol B., 1999. Assessing tree and stand biomass: a review with examples and critical comparisons. For. Sci. 45: 573-593.

Pilli R., Anfodillo T., and Carrer M., 2006. Towards a functional and simplified allometrry for estimating forest biomass. For. Ecol. Manage. 237: 583-593.

Putz F.E., 1983. Liana biomass and leaf area of "tierra firme" forest in the Rio Negro basin, Venezuela. Biotropica 15: 185-189.

Reynolds J., Marathon G., Rosales L., and Wright J., 2000. Ecuaciones de volumen y peso para Eucalyptus urophylla y Eucalyptus grandis. Informe de Investigación No. 21, Smurfit-Carton de Venezuela.

Rodríguez R., Hofmann G., Espinoza M., and Ríos D., 2003. Biomasa partitioning and leaf area of Pinus radiata trees sunjected to silvopastoral and conventional forestry in the VI Region, Chile. Revista Chilena de Historia Natural 76: 437-449.

Rodríguez-Laguna R., Jiménez-Pérez J., Aguirre-Calderon O., and Jurado-Ibarra E., 2007. Ecuaciones alométricas para estimar biomasa aérea en especies de encino y pino en Irurbide, N.L. Ciencia Forestal en México 32: 39-56.

Rojo-Martínez G.E., Jasso-Mata J., Vargas-Hernández J., Palma-López D.J., and Velásquez-Martínez A., 2005. Biomasa aérea en plantaciones comerciales de hule (Hevea brasiliensis Mull Arg.) en el estado de Oaxaca, México. Agrociencia 39: 449-456.

Saldarriaga J.G., West D.C., Tharp M.L., and Uhl C., 1988. Long term chronosequence of forest succession in the upper Rio Negro of Colombia and Venezuela. J. Ecol. 76: 938-958.

Salis S.M., Assis M.A., Mattos P.P., and Piao A.S.S., 2006. Estimating the aboveground biomass and wood volume of savanna woodlands in Brazil's Pantanal wetlands based on allometric correlations. For. Ecol. Manage. 228: 61-68.

Sampaio E.V.S.B., and Silva G.C., 2005. Biomass equations for Brazilian semiarid caatinga plants. Acta Botânica Brasílica 19: 935-945.

Sanquetta C.R., Watzlawick L.F., and Arce J.E., 2002. Ecuaciones de biomasa aérea y subterránea en plantaciones de Pinus taeda en el sur del Estado de Paraná, Brasil. Patagonia Forestal. http://www.ciefap. org.ar/patagoniaforestal/2002-1/biomassa_pinus.htm.
Saunders M. and Wagner R.G., 2008. Height-diameter models with random coefficients and site variables for trees species of Central Maine. Ann. For. Sci. 65: 203.

Segura M., Kanninen M., and Suarez D., 2006. Allometric models for estimating aboveground biomass of shade trees and coffee bushes grown together. Agrofor. Syst. 68: 143-150.

Scatena F.N., Silver W., Sicamma T., Jonson A., and Sanchez M.J., 1993. Biomass and nutrient content of the Bisley experimental watersheds, Luquillo Experimental Forest, Puerto Rico before and after hurricane Hugo, 1989. Biotropica 25: 15-27.

Schlegel B., 2001. Estimación de biomasa y carbono en bosques del tipo forestal siempreverde. Simposio Internacional de Medición y Monitoreo de la Captura de Carbono en Ecosistemas Forestales, Valdivia, Chile, 18-21 Octubre de 2001.

Schnitzer S.A., DeWalt S.J., and Chave J., 2006. Censusing and measuring lianas: a quantitative comparison of the common methods. Biotropica 38: 581-591

Schroeder P., Brown S., Mo J., Birdsey R., and Cieszewski C., 1997. Biomass estimation for temperate broadleaf forest of the United States using inventory data. For. Sci. 43: 424-434.

Sierra C.A., del Valle J.I., Orrego S.A., Moreno F.H., Harmon M.E., Zapata M., Colorado G.J., Herrera M.A., Lara W., Restrepo D.E., Berrouet L.M., Loaiza L.M., and Benjumea J.F., 2007. Total carbon stocks in a tropical forest landscape of the Porce region, Colombia. For. Ecol. Manage. 243: 209-309.

Sierra C.A., 2001. Biomasa de raíces en bosques primarios y secundarios del área de influencia de la central hidroelectrica Porce II. Trabajo de Grado, Universidad Nacional de Colombia, Sede Medellín, Medellín, Colombia.

Ter-Mikaelian M.T. and Korzukhin M.D., 1997. Biomass equations for sixty five North American tree species. For. Ecol. Manage. 97: 1-24.

Uhl C., Buschbacher R., and Serrao E.A.S., 1988. Abandoned pastures in eastern Amazonia. I Patterns of plant succession. J. Ecol. 76: 663681.

Vidal-Corona A., Rodríguez J.R., Naranjo J.Y.B., Rivera R.C.A., and Ríos H.G., 2004. Estimación de la biomasa de copa para árboles en pie de Pinus tropicalis Morelet en la empresa forestal integral Macurije de la Provincia de Pinar del Río, Cuba. Revista Floresta 32: 261-265.

Vargas R., Allen M.F., and Allen E.B., 2008. Biomass and carbon accumulation in a fire chronosequence of a seasonally dry tropical forest. Glob. Change Biol. 14: 109-124.

Weaver P.L., 2002. A chronology of hurricane induced changes in Puerto Rico's lower montane forest. Interciencia 27: 252-258.

Weaver P.L. and Gillespie A.J.R., 1992. Tree biomass equations for the forests of the Luquillo Mountains, Puerto Rico. Commonwealth Forestry Review 71: 35-39.

West G.B., Brown J.H., and Enquist B.J., 1999. A general model for the structure and allometry of plant vascular system. Nature 400: 664667.

Zapata M., del Valle J.I., and Orrego S.A., 2001. Corrección por sesgo en los modelos log-normales alométricos linealizados utilizados para la estimación de la biomasa aérea. Simposio Internacional de Medición y Monitoreo de la Captura de Carbono en Ecosistemas Forestales, Valdivia, Chile. 18-21 Octubre de 2001.

Zianis D. and Mencuccini M., 2004. On simplifying allometric analysis of forest biomass. For. Ecol. Manage. 23: 311-332. 